\title{
Expected and Unexpected Consequences of Russian Pension Increase in 2010
}

\author{
Ivan Suvorov, University of North Carolina at Chapel Hill ${ }^{1}$ \\ isuvorov@live.unc.edu
}

This paper studies the effects of the pension increase in Russia in 2010 on the labour force participation decisions and living arrangements of senior people and their family members. There is not much research on the effects of pension rises in Russia. In particular, researchers have not yet analysed the influence of pension increases in Russia on nonelderly people nor the heterogeneity of this influence. The increase in pensions in 2010 is of particular interest due to its unique magnitude, its relative independence from economic trends in Russia at that time, and its plausible exogeneity for pensioners.

This study provides evidence that this jump in pension caused an approximately 5 percentage point increase in the relative number of seniors who chose to retire. The effect was stronger in the two biggest cities of Russia, namely Moscow and Saint Petersburg, where before 2010 a substantial number of people continued to work after reaching the pension age. One out of four employed pensioners living in these cities left the labour force in 2010. In addition, this paper shows a relatively unexpected external effect on younger individuals. The labour force participation decisions of younger people who lived with pension receivers were influenced considerably. The non-seniors who lived with pensioners, compared with their peers, were less likely to work or to look for jobs. The change in pensions also affected living arrangements. The rate of pension receivers living with their children and grandchildren went up significantly. Thus, the evidence from the 2010 pension increase highlights the fact that policies might have an impact not only on the target group of population, but on the family members of this group as well.

Keywords: labour force participation, pensions, retirement

JEL Codes: J14, J26

\begin{abstract}
Citation: Suvorov, I. (2020). Expected and Unexpected Consequences of Russian Pension Increase in 2010. Russian Journal of Money and Finance, 79(1), pp. 93-112.
\end{abstract}

doi: $10.31477 /$ rjmf.202001.92

\footnotetext{
${ }^{1}$ The author is a New Economic School (MAE'19) graduate, a winner of the 2019 Economic Research Competition organised by the Bank of Russia and the Russian Journal of Money and Finance for students and postgraduates, a PhD student of the University of North Carolina at Chapel Hill.
} 


\section{Introduction}

The pension system is an important issue in Russia. In 2010, total retirement benefits in Russia were as large as $10 \%$ of Russian GDP. ${ }^{2}$ The Russian Federation inherited a pay-as-you-go system from the Union of Soviet Socialist Republics. During his presidency Vladimir Putin has already introduced two significant reforms of the Russian pension system (in 2002 and 2005). Recently, in 2018, president Putin started a new reform. According to many economists, the reform was long overdue. The reform is expected to be significant enough to have a considerable impact on the Russian economy as a whole. To understand the potential consequences of this reform, it is important to analyse the previous changes in the Russian pension system.

A number of articles have been devoted to the Russian pension system and its changes. My research concentrates on the study of the consequences of pension increases in Russia. There is little research on this particular topic.

Some articles analyse the pension system during Russia's transition from a state-planned to a market-based economy and provide ideas for further modifications. De Castello Branco (1998), who performed such an analysis, proposed improving the existing pay-as-you-go system and only then focusing on a more complex structure.

The 2002 Russian pension reform is a relatively well-studied case. Gontmakher (2009) stresses the complexity of the pre-reform situation. In Gel'man (2017), the 2002 Russian pension reform is described as a compromise between quite different policy positions. Despite the fact that the compromise was achieved, the reform did not tackle the problems of the pension system. Afanasiev (2003) highlights the drawbacks of the 2002 pension reform. On the other hand, Kovrova (2007) manages to find positive effects of that reform as well as of the 2005 Russian pension reform.

Overall, even after the 2002 and 2005 Russian pension reforms, researchers have held a consensus about the presence of significant unsolved problems in the Russian pension system. Economists repeatedly suggested an increase of the pension age in Russia (Sinyavskaya, 2005; Hauner, 2008; Maleva and Sinyavskaya, 2010; Gurvich and Sonina, 2012). It is only today that the pension age is finally increasing in the country. The 2018 pension reform gradually increases the current pension age from 55 to 60 for females and from 60 to 65 for males. Supporters of the reform underline that the pension age increase will allow a significant increase in the size of pensions. ${ }^{3}$

In contrast to the researchers, Russian society did not expect the pension age to increase. ${ }^{4}$ The initial public reaction to the reform was unambiguously negative. ${ }^{5}$

\footnotetext{
${ }^{2}$ See https://www.vesti.ru/doc.html?id=316634

${ }^{3}$ See https://tass.ru/ekonomika/5290888

${ }^{4}$ See https://carnegie.ru/commentary/77015

${ }^{5}$ See https://fom.ru/posts/14043
} 
President Putin made an attempt to change public opinion and spoke to the nation about this issue personally. ${ }^{6}$ This did not help change the situation. Local elections were held in September 2018. In spite of the support of the president, many pro-government candidates failed to win the elections. Some political observers claim that it was the pension reform which caused these failures.

Overall, the existing research on the topic had the following goals: analysis of the 2002 and 2005 pension reforms, the identification of the effective pension age (Sinyavskaya, 2005), the examination of the problems of the Russian pension system (Gurvich and Sonina, 2012) and the reasons for them (Solovyev, 2013), discussion of the pros and cons of possible pension age increase (Maleva and Sinyavskaya, 2010), and the study of the determinants of senior people's participation in the labour force (Danielyan, 2016; Lyashok, 2017). What is completely missing in the research in this area so far is the analysis of the economic and social effects of a pension increase on other groups of the population and the study of the heterogeneity of these effects. My research aims to fill this gap.

The rise in pensions in 2010 was of a unique magnitude. The outstanding scale of that rise was initially underlined in the research by Lyashok (2017). In addition to the magnitude, Lyashok highlighted the exogeneity of the increase (from the viewpoint of pensioners) and the independence of that rise from economic trends as a rationale to study this particular rise. I furthermore underline the independence of that pension increase from economic trends in Russia at that time. The average real incomes of non-retired and retired people followed common trends throughout all recent years except for the jump in 2010Q1 (see Figure 1). The 2010 pension increase allows the separation of the effect of pension rises from the influence of all such variables correlated with these changes. The unique magnitude of the 2010 pension increase allows the removal of possible bias due to the omitted variables. One of such examples is an individual's health. Having stronger health, a person is more likely to stay in the labour force and have higher wages and pension, ceteris paribus. Concentration on the sharp pension increase of 2010 makes it possible to see the effects of pension increase per se. The consequences of a sharp increase in pension can provide an idea about the possible aftermath of other changes in the Russian pension system, including the current reform.

My work relates to the literature addressing the relationship between retirement and pensions (see e.g. Malkova, 2020; Lyashok, 2017; Manoli and Weber, 2016). I expected to see that a sharp increase in retirement benefits led to the retirement of a higher percentage of senior people. Indeed, my research proved this to be true. Furthermore, the research of Schröder-Butterfill (2004) demonstrates that inter-generational family support provided by older people can

\footnotetext{
${ }^{6}$ See https://www.youtube.com/watch?v=1UYMdAABvnw

${ }^{7}$ See https://www.pravda.ru/news/politics/1392918-edinorossy/
} 
influence the degree of economic independence of their children. With higher pensions, elderly people are capable of providing more significant support to their relatives. Therefore, I expected to find an external effect caused by the 2010 pension increase on employment among younger adults living with their retired parents. I found that this is true. Additionally, I expected to see evidence to support the result of Gruber et al. (2009) about the absence of substitution between older and younger workers. Again, the findings met expectations.

In addition, I found an effect on living arrangements. The existing evidence is ambiguous on this issue. Bianchi (1987) and Young (1987) show that large family economic resources increase the probability of coresidence. Similarly, Manacorda and Moretti (2006) show that higher income of seniors raised the proportion of men coresiding with their parents. However, Goldscheider and DaVanzo (1989) suggest that parents' large income increases the likelihood of children leaving parents' homes. Specifically in the Russian case, Lokshin et al. (2000) show that in times of economic downturn, single mothers prefer to coreside. My research in turn indicates that the effect of Russian seniors' acute increase in income on coresidence with younger generations is a positive one.

My research emphasises the fact that a policy might have an effect not only on the intended group, but also on their relatives and other family members. In particular, my findings are relevant to the current 2018 pension reform in Russia. In order to make predictions about the consequences of this reform, one has to analyse the aftermath of previous significant changes in the Russian pension system. The results of my research provide an idea about possible consequences of the current reform and elucidate some characteristics of Russian society in general. While enriching the literature on the Russian pension system, my research also contributes to the research on labour and family economics.

The rest of this paper is organised as follows. Section 2 provides background information. Section 3 describes the data. Section 4 discusses the empirical strategy. Section 5 presents the main results. Section 6 makes robustness checks, provides some historical evidence, and explores heterogeneity. Section 7 discusses the findings. Section 8 concludes.

\section{Background}

Speaking about federal expenditures on retirement benefits in 2010, Vladimir Putin pointed out that these expenditures were the highest in Russian history. ${ }^{8}$ Despite the fact that the 2010 pension increase was of a unique magnitude, the authorities had announced it just a few months before ${ }^{9}$ and senior people did not expect such a sharp rise in pensions. This increase in pensions was based on the law on labour pension and did not influence special groups of people who retired

\footnotetext{
${ }^{8}$ See https://www.vesti.ru/doc.html?id=316634

${ }^{9}$ See https://ria.ru/20091130/196272604.html
} 
earlier, such as military officials. The 2010 pension increase was calculated based on employment history and the cost of living in the region. ${ }^{10}$ Some economists expressed concern whether the government would be able to maintain the high level of pensions in 2010 as it was. ${ }^{11}$ In nominal terms, the average pension increased from 4909.8 rubles at the start of 2009 to 8156.8 rubles (66\% larger) at the beginning of $2011 .^{12}$

It is important to note that the state pension is a major part of the income of most retired Russian individuals. Despite the 2010 rise and regular increases in pensions, ${ }^{13}$ these particular social benefits are considered to be quite smallRussians say that the pensions they deserve should be more than twice as high as they are now. ${ }^{14}$ However, the majority of Russians believe that the pension will be their major source income when they reach the pension age. ${ }^{15}$

The significance of pensions and the opinions of retired people is considerable in Russian politics. ${ }^{16}$ Opportunistic cycles in pensions can be an expected finding. On the other hand, the general public and the media tend to become more interested in retired individuals during the anniversaries of the victory in World War II. Before any anniversary, the media usually compares the well-being of retirees in Russia and Germany. ${ }^{17}$

The celebrations of the victory in World War II, so called 'Victory Days', are becoming more and more significant in Russia, ${ }^{18}$ therefore, an influence of World War II victory anniversaries on pension size can be anticipated. Durante and Zhuravskaya (2016) demonstrate that politicians can exploit special events to conceal their misdeeds. 'Victory Days' also illustrate the fact that politicians also exploit such special occasions to show off.

\section{Data}

In my study, I utilise two datasets. The first dataset being used is the quarterly data from the Household Budget Survey (HHBS) by the Rosstat. ${ }^{19}$ The HHBS is a nationally representative survey. I use the data on observations between 2003 and 2015. The Rosstat provides databases for each quarter of the year. Furthermore, for each quarter there is a database with information about income, then there is a separate database with information about sources of income, and finally there is another dataset about the characteristics of

\footnotetext{
${ }^{10}$ See http://xn--blagvbq6g.xn--plai/news/economy/valorisation/

${ }^{11}$ e.g. see https://echo.msk.ru/blog/gontmaher/637242-echo/

12 see https://www.fedstat.ru/indicator/31455

${ }^{13}$ See https://tass.ru/info/4853990

14 e.g. see https://tass.ru/ekonomika/7060617

${ }^{15}$ See https://fom.ru/Ekonomika/14079

${ }^{16}$ See https://www.bbc.com/russian/russia/2010/09/100908_putin_pensions_politics

17 e.g. see https://www.newsru.com/finance/09may2013/pensii.html

${ }^{18}$ See https://youtu.be/nZs2ajTKpRw

${ }^{19}$ See https://gks.ru/folder/13397
} 
households' members. More than 100,000 individuals within approximately 50,000 households are surveyed each quarter.

The second dataset being used is the Russian Longitudinal Monitoring Survey - Higher School of Economics (RLMS-HSE). ${ }^{20}$ The RLMS-HSE is an annually run nation-wide representative study designed to analyse the consequences of the Russian reforms on the welfare of Russian households and individuals. The RLMS-HSE contains questions about individuals' objective and subjective well-being. Each year approximately 15,000 individuals who comprise more than 5,000 households are surveyed. The survey is conducted in the period between October and December. I use the data on observations between 2000 and 2018 .

In this study, there will be terms which will be specific for this paper only. Senior people are respondents of pension age, i.e. men older than 60 and women older than 55. A retired household is a household which has pension as the main source of income. The HHBS contains a direct question about the major source of income. As for the RLMS, I choose retired households based on the criterion that their income from pension is more than half of their total income. Respondents of working age are people who are younger than the pension age but who are older than 18 at the time of survey. NLFJ means the percentage of the respondents of working age who both did not work and did not look for a job for the whole quarter. The head of a household is the member of a household who brings in the major part of the household's income. Household employment is the employment of the head of a house and/or her/his spouse. Relative income is defined in this paper as the income of an individual divided by the average income of all respondents that year or a quarter of that year. The CPI ${ }^{21}$ is used in order to account for inflation.

The HHBS dataset has its limitations. Only the total income of a household $(\mathrm{HH})$ is specified. The question about the main source of income is asked in this survey and a pension is one of the possible answers. This allows me to consider retired households. However, the reasons for a $\mathrm{HH}$ member to get a pension are not listed in this question about the major source of income. As a result, the main source of income for some retired households could be, for example, a military pension due to the recent military service of $\mathrm{HH}$ members. The income of such HHs was not considerably influenced by the 2010 pension increase, if it was influenced at all. I analyse these retired households only so as to support the evidence of the significance of the 2010 pension increase and I also use these households one more time so as to show an increase in the number of households that live on pensions. In both cases, the presence of a group which was not influenced by the 2010 pension increase is expected to make the changes

\footnotetext{
${ }^{20}$ See https://www.hse.ru/en/rlms/

${ }^{21}$ See http://www.gks.ru/free_doc/new_site/prices/potr/tab-potr1.htm
} 
I am looking at less significant. The fact that these changes are apparent even with the presence of a group who were not considerably influenced by the 2010 pension increase speaks for the significance of these changes.

\section{Empirical strategy}

My identification strategy is based on a regression discontinuity (RD) design and a difference-in-differences technique (see Angrist and Pischke, 2009; Cameron and Trivedi, 2005; Lee and Lemieux, 2010). RD estimates treatment effects in a quasi-experimental setting where treatment is determined by whether some assignment variable exceeds a known cutoff point. In my case, the treatment is the pension increase in 2010 and the assignment variable is time. Under the reasonable assumption that other variables which could influence the variables of interests do not jump in 2010Q1 (see the discussion of this issue in Introduction), RD can identify pension increase and its effects on Russians. Based on this technique, I explore jumps in 2010Q1 and in the years of anniversaries of the World War II victory using the following specifications:

$$
\begin{aligned}
& Y_{i t}=\text { const }+\beta_{1} * I_{t>=2010}+\beta_{2} * f(t)+ \\
& \beta_{3} * I_{t>2010} * f(t)+g(t)+\epsilon_{i t}, \\
& Y_{i t}=\text { const }+\beta_{1} * I_{\text {Anniversary }}+\beta_{2} * I_{\text {OneYearAroundAnniversary }}+ \\
& \beta_{3} * f(t)+g(t)+\epsilon_{i t},
\end{aligned}
$$

where $Y_{i t}$ is the variable of interest, $f(t)$ stands for the linear trend variable, and $g(t)$ stands for the time-fixed effects (seasonal dummies). $\beta_{1}$ is the main coefficient in these regressions: it shows a change in the variable of interest in 2010Q1 or in an anniversary year relative to the trend and seasonal fluctuations.

The difference-in-differences technique studies the differential effect of a treatment on a treatment group versus a control group in a natural experiment. In my case, my treatment group are younger people living in households with retired senior people and my control group are those living in households without retired seniors. The technique is implemented by the following specification:

$$
\begin{aligned}
& Y_{i t}=\text { const }+\beta_{1} * I_{t>=2010} * I_{\text {RetiredInH } H}+\beta_{2} * I_{\text {RetiredInH } H}+ \\
& \beta_{3} * I_{t>=2010}+\beta_{4} * f(t)+\beta_{5} * I_{t>2010} * f(t)+g(t)+\epsilon_{i t},
\end{aligned}
$$

where $I_{\text {RetiredInHH }}$ is an indicator for the presence in the household of a person who receives a pension. Variables of interest, $Y_{i t}$, stand for the indicator that illustrates that a person worked for the whole quarter of the year (see Table 2) and the 
indicator that shows that a person was out of labour force for a whole quarter of the year (see Table 3 ). $\beta_{1}$ is the main coefficient. It shows a change in the variable of interest in 2010Q1 relative to the trend and seasonal fluctuations among the respondents of a treatment group in comparison to a control group. Figures 10 and 11 confirm the parallel pre-trends assumption which is necessary for the identification of true $\beta_{1}$. Standard errors in all regressions are clustered by regions and the types of settlement.

\section{Main results}

Lyashok (2017) identified and analysed the sharp increase in pensions in 2010 with the RLMS only. I support the identification and perform analysis of that jump in pensions using the more frequent HHBS in addition to the RLMS. Both graphs and regressions provide evidence of a discontinuity in the income of retired households and individuals in 2010Q1 (see Table 1, Figure 2). Regressions show that the jump in income of retired households and individuals was around $30 \%$, which is in line with Lyashok's results.

Lyashok (2017) concentrated on the influence of the 2010 pension rise on retirement decisions. I continue Lyashok's analysis in several directions. Firstly, I check for the heterogeneity of that pension increase with respect to the pensioners' place of living. Next, I explore the heterogeneity of the effects of that pension rise. Finally, I study the impact of that 2010 jump in pensions on other population groups.

As Figure 3 shows, retired individuals living in cities are always better-off than those residing in rural areas in terms of real income. The 2010 pension increase appears to be homogeneous with respect to place of living. The discontinuity is clear in the relative income of both types of retired individuals, rural and urban (see Figure 4).

Lyashok (2017) analysed changes in retirement decisions using RLMS data. I show the discontinuity in the labour force participation of pensioners via the more frequent HHBS data (see Figure 5). In 2010, the percentage of seniors who were not working went up by 5 percentage point (p.p.), from $69 \%$ to $74 \%$, which is similar to the results of Lyashok (2017). Rural labour markets were hardly influenced by the 2010 pension increase, while those of Moscow and Saint Petersburg were influenced dramatically (see Figures 6 and 7). Due to these changes in retirement decisions, the average age of working pension receivers changed. The discontinuity in the average age of working male pensioners is considerable (see Figure 8). Retirement was hardly forced. Respondents almost always claim that retirement was their own decision (see Figure 9). All the above mentioned demonstrates that the 2010 rise in pension resulted in a jump in retirement.

The pension increase in 2010 influenced employment not only among pension receivers, but among younger people as well. Respondents of working 
age who live with pensioners were affected most (see Figures 10 and 11). The difference-in-differences technique is used in order to see the impact of coresidence with pensioners on the relation to employment among such respondents (see Tables 2, 3). All these changes led to a jump in the percentage of retired households (see Figure 12).

Table 1. The discontinuity in the real income of retired individuals and HHs in 2010

\begin{tabular}{lll} 
Variables & $\begin{array}{l}\text { RLMS retired individuals } \\
\log (\text { real income) }\end{array}$ & $\begin{array}{l}\text { HHBS retired HH } \\
\log (\text { real income) }\end{array}$ \\
\hline \multirow{2}{*}{$I_{t>=2010}$} & $0.208^{* * *}$ & $0.197^{* * *}$ \\
\hline \multirow{2}{*}{ Trend } & $(0.0133)$ & $(0.0159)$ \\
\hline \multirow{2}{*}{ Trend $\times I_{t>=2010}$} & $0.0943^{* * *}$ & $0.103^{* * *}$ \\
& $(0.00207)$ & $(0.00476)$ \\
\hline \multirow{2}{*}{ Constant } & $-0.0930^{* * *}$ & $-0.0714^{* * *}$ \\
& $(0.00314)$ & $(0.00605)$ \\
\hline Seasonal Dummies & $6.804^{* * *}$ & $8.702^{* * *}$ \\
\hline Observations & $(0.0343)$ & $(0.0149)$ \\
\hline R-squared & - & Yes \\
\hline
\end{tabular}

Note: robust standard errors in parentheses; ${ }^{* *}-\mathrm{p}<0.01$.

Table 2. Difference-in-differences estimation of the pension increase effect on the employment of respondents of working age

\begin{tabular}{ll} 
Variables & $\begin{array}{l}\text { Non-employed } \\
\text { respondents of working } \\
\text { age not looking for a lob } \\
\text { for a whole quarter }\end{array}$ \\
\hline$I_{\text {RetiredInHH }} \times I_{t>=2010}$ & $\begin{array}{l}-0.0285^{* * *} \\
(0.00565)\end{array}$ \\
\hline$I_{\text {RetiredInHH }}$ & $\begin{array}{l}-0.0544^{* * *} \\
(0.00519)\end{array}$ \\
\hline$I_{t>=2010}$ & $\begin{array}{l}-0.0113^{* * *} \\
(0.00422)\end{array}$ \\
\hline Trend & $\begin{array}{l}0.00589^{* * *} \\
(0.00171)\end{array}$ \\
\hline Trend $\times I_{t>=2010}$ & $\begin{array}{l}0.00337 \\
(0.00211)\end{array}$ \\
\hline Constant & $0.771^{* * *}$ \\
\hline Seasonal Dummies & $(0.00615)$ \\
\hline Observations & $3,860,070$ \\
\hline R-squared & 0.006 \\
\hline
\end{tabular}

Note: robust standard errors in parentheses; $\star * *-\mathrm{p}<0.01$

Source: HHBS, author's calculations
Table 3. Difference-in-differences estimation of the pension increase effect on the desire of non-employed respondents of working age not to look for a job

\begin{tabular}{|c|c|}
\hline Variables & $\begin{array}{l}\text { Non-employed } \\
\text { respondents of working } \\
\text { age not looking for a lob } \\
\text { for a whole quarter }\end{array}$ \\
\hline$I_{\text {RetiredInHH }} \times I_{t>=2010}$ & $\begin{array}{l}0.0214^{* * *} \\
(0.00468)\end{array}$ \\
\hline$I_{\text {RetiredInHH }}$ & $\begin{array}{l}0.0458^{\star * *} \\
(0.00401)\end{array}$ \\
\hline$I_{t>=2010}$ & $\begin{array}{l}0.000513 \\
(0.00340)\end{array}$ \\
\hline Trend & $\begin{array}{l}-0.00537^{\star * *} \\
(0.00126)\end{array}$ \\
\hline Trend $x I_{t>=2010}$ & $\begin{array}{l}0.000525 \\
(0.00155)\end{array}$ \\
\hline Constant & $\begin{array}{l}0.193^{* * *} \\
(0.00445)\end{array}$ \\
\hline Seasonal Dummies & Yes \\
\hline Observations & $3,860,070$ \\
\hline R-squared & 0.005 \\
\hline
\end{tabular}

Note: robust standard errors in parentheses; $* * *-\mathrm{p}<0.01$.

Source: HHBS, author's calculations 
Figure 1. The average real income of $\mathrm{HHs}$ without seniors and that of households living on pensions

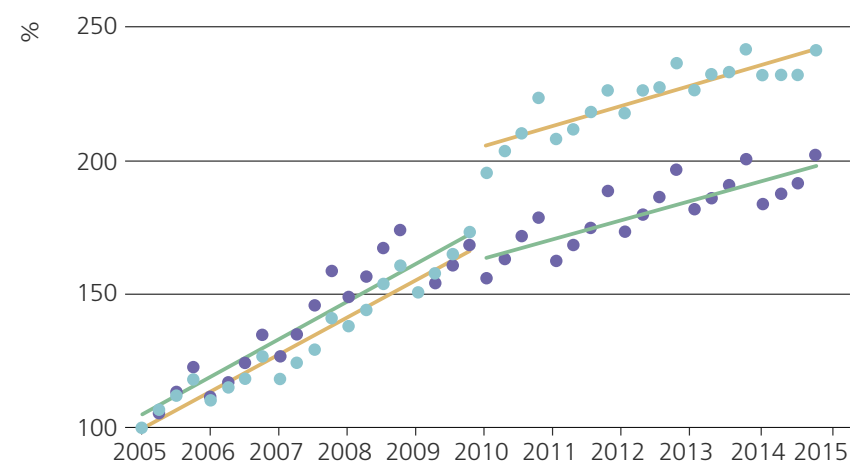

- HHs without seniors, quarter average

- retired $\mathrm{HHs}$, quarter average

_ HHs without seniors trend

— retired $\mathrm{HHs}$ trend

Source: HHBS, author's calculations

Figure 2. The real income of retired households

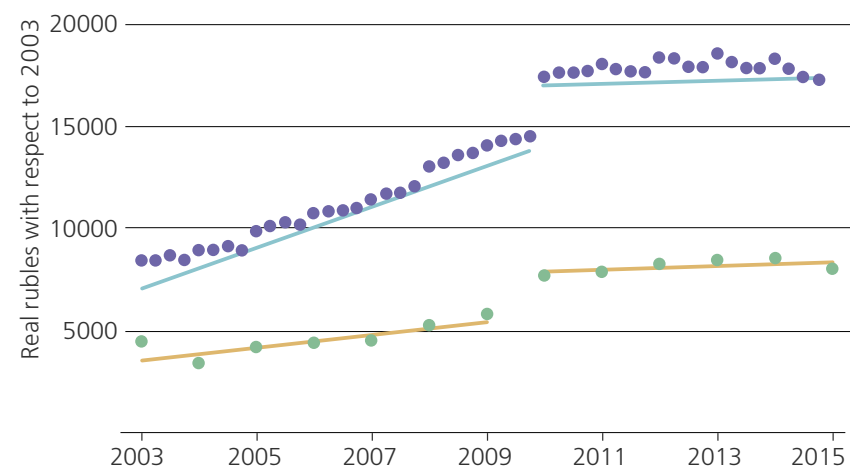

- HHBS quarter average

- RLMS quarter average

— HHBS trend

— RLMS trend

Source: RLMS, HHBS, author's calculations

Figure 3. The real income of retired people

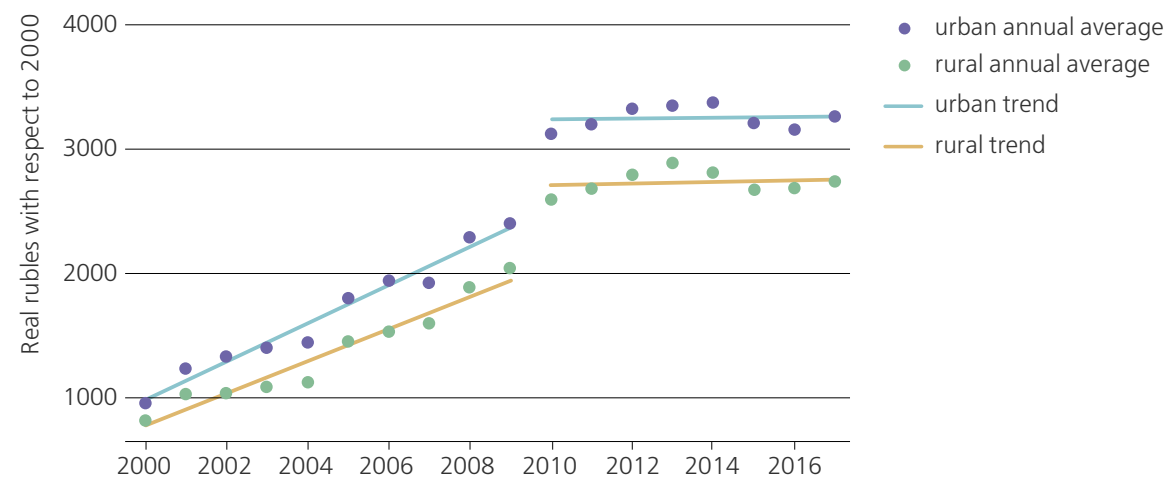

Source: RLMS, author's calculations 
Figure 4. The relative income of retired people with respect to all respendents

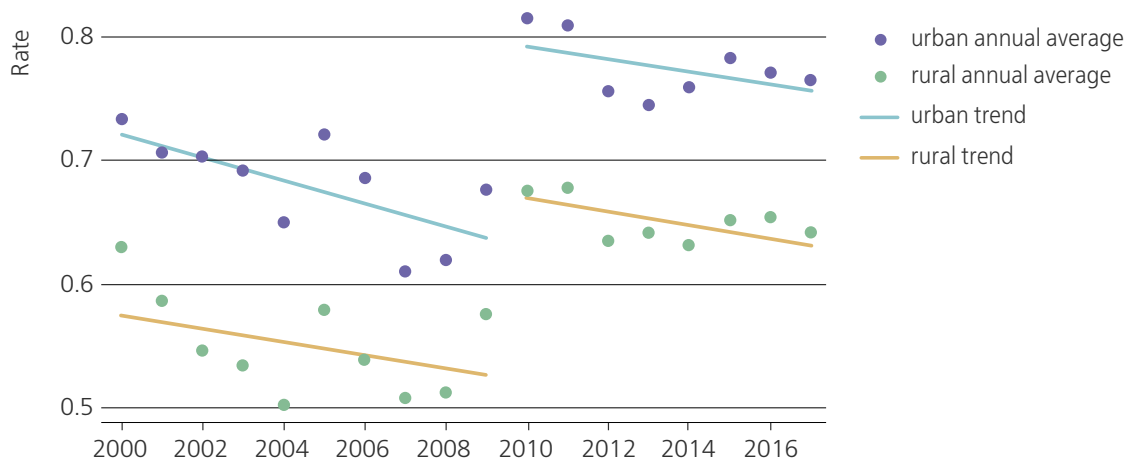

Source: RLMS, author's calculations

Figure 5. The percentages of seniors who did not work for the whole quarter

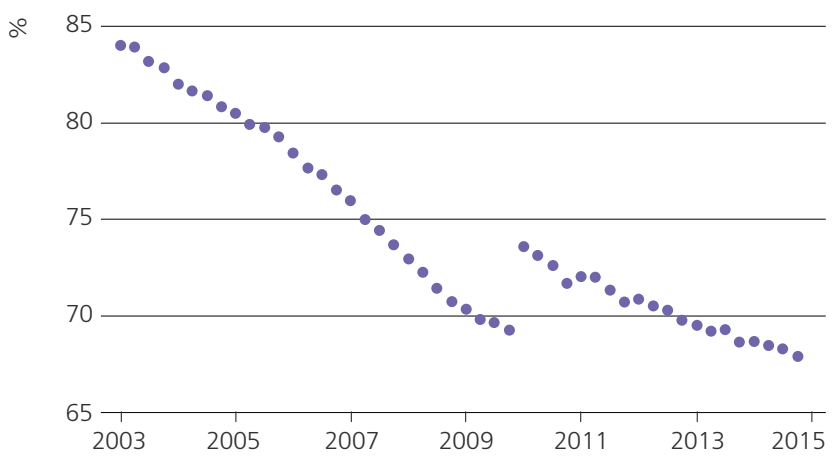

Source: HHBS, author's calculations

Figure 6. The percentages of seniors who worked for the whole quarter and lived in rural areas, Moscow or Saint Petersburg

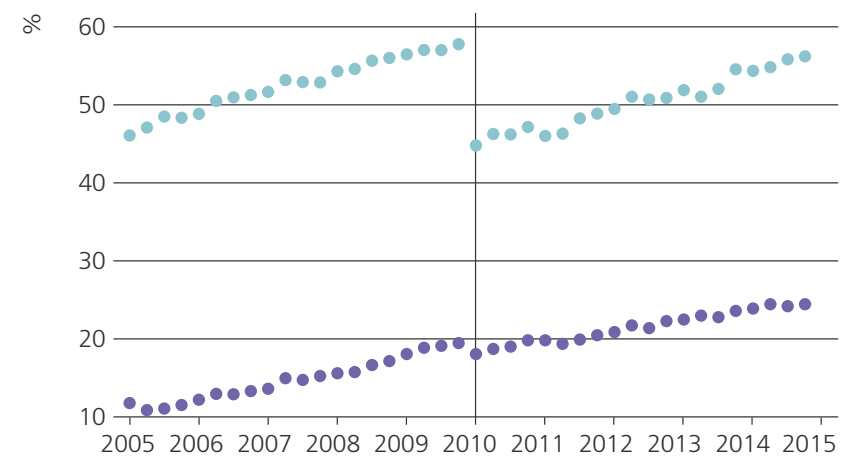
- live in rural areas
- live in Moscow or Saint-Petersburg

Source: HHBS, author's calculations 
Figure 7. The log percentage of seniors who worked for the whole quarter and lived in rural areas, Moscow or Saint Petersburg

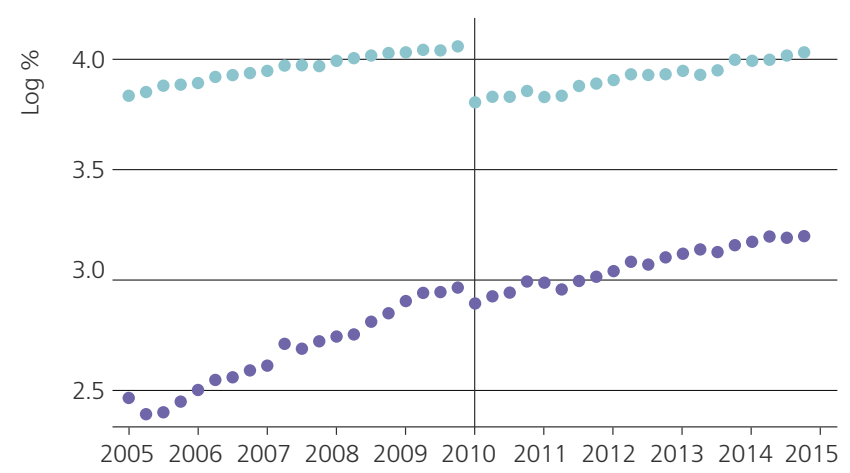

- live in rural areas

- live in Moscow or Saint-Petersburg

Source: HHBS, author's calculations

Figure 8 . The average age of working male seniors

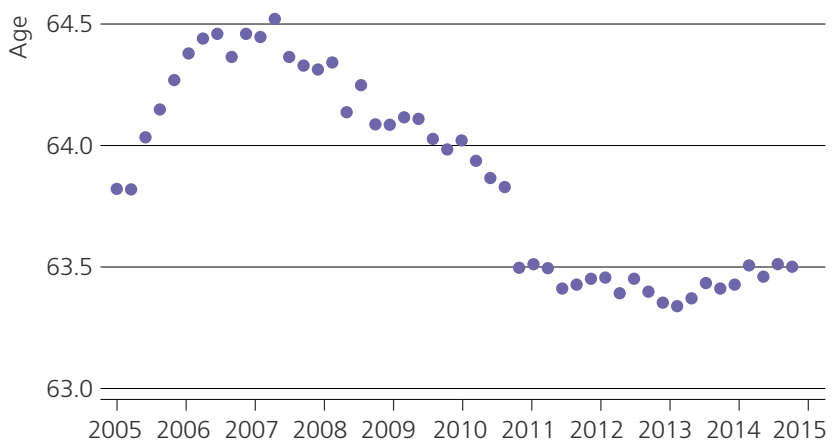

Note: the graph shows the average age of males who are older than 'retirement age' and continue to work.

Source: HHBS, author's calculations

Figure 9. The rate of seniors who were forced to leave a job by their employer as a share of seniors who left their jobs

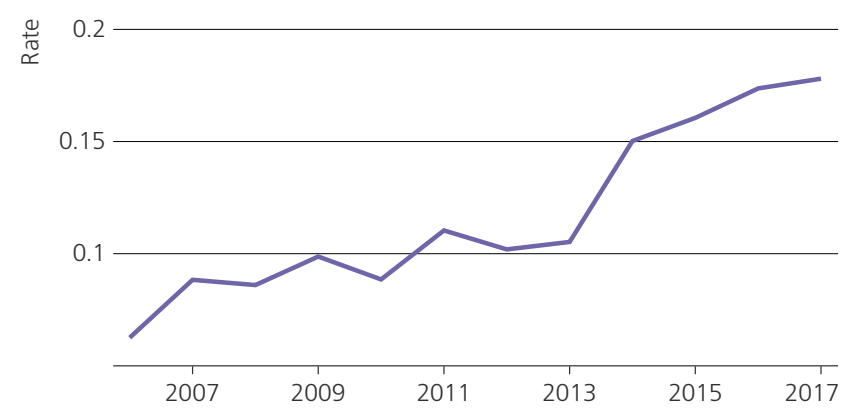

Note: see Appendix C for details.

Source: RLMS, author's calculations 
Figure 10. The percentages of respondents of working age who did not work for the whole quarter

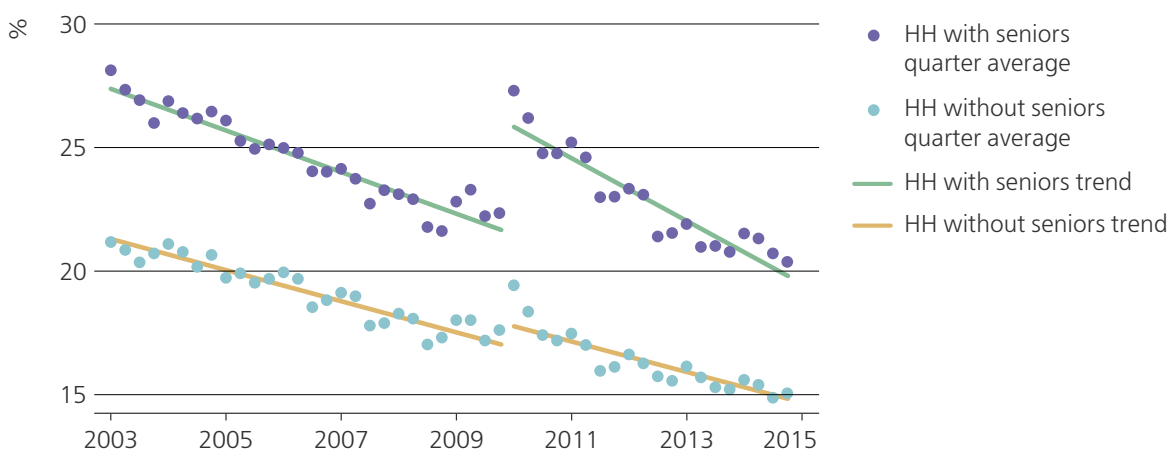

Source: HHBS, author's calculations

Figure 11. The percentages of respondents of working age who did not work and did not look for a job for the whole quarter

๖

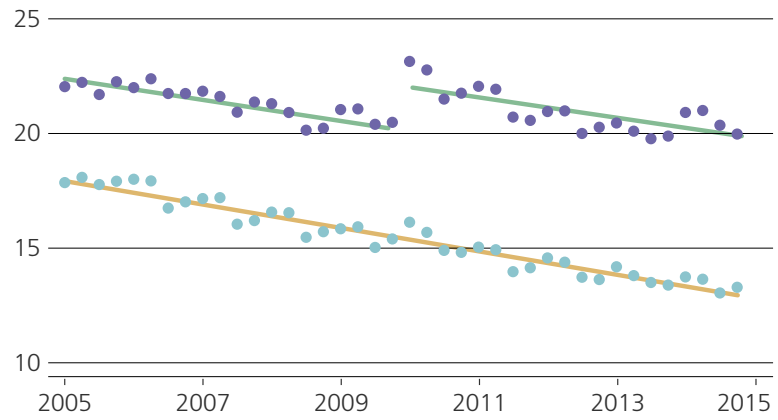

Source: HHBS, author's calculations

Figure 12. The rate for retired $\mathrm{HHs}$ as a share of $\mathrm{HHs}$ with seniors

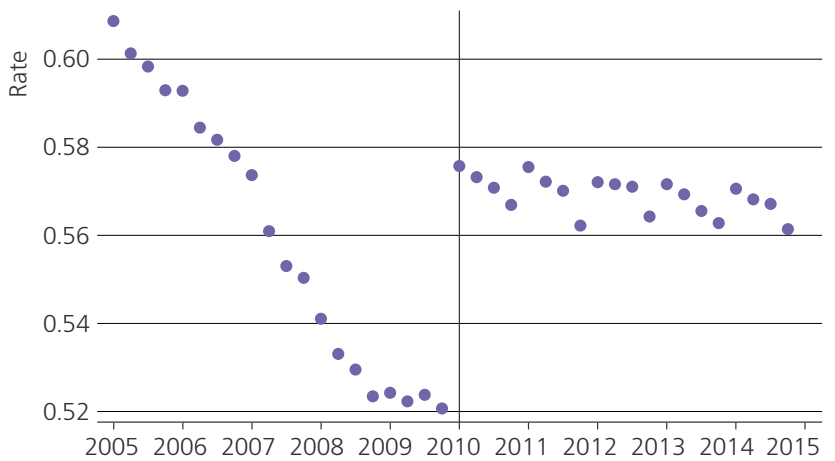

Source: HHBS, author's calculations
- HH with seniors quarter average

- HH without seniors quarter average

- $\mathrm{HH}$ with seniors trend

- $\mathrm{HH}$ without seniors trend 
Figure 13. The rate for $\mathrm{HHs}$ with only seniors as a share of $\mathrm{HHs}$ with seniors

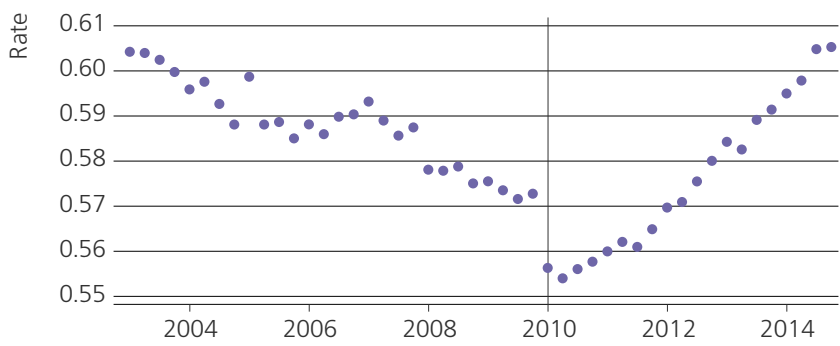

Source: HHBS, author's calculations

Figure 14. The rate for $\mathrm{HHs}$ with children and seniors as a share of $\mathrm{HHs}$ with seniors

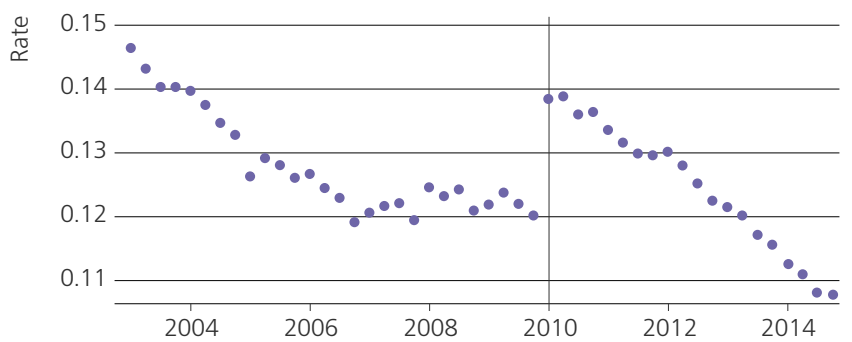

Note: children are people younger than 18 years old.

Source: HHBS, author's calculations

Figure 15. The average number of people in retired households

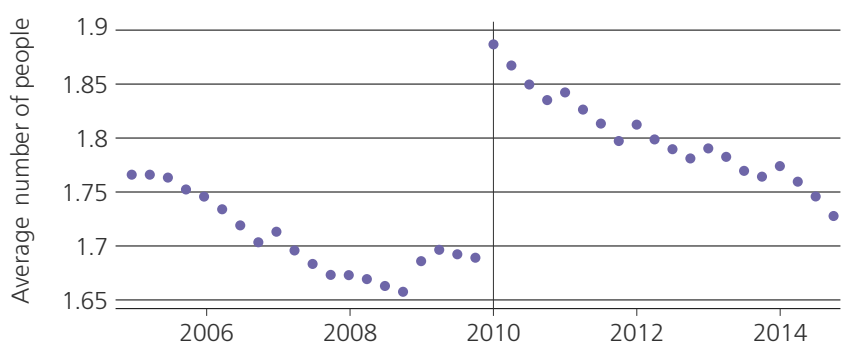

Source: HHBS, author's calculations

Figure 16. The real income of retired households

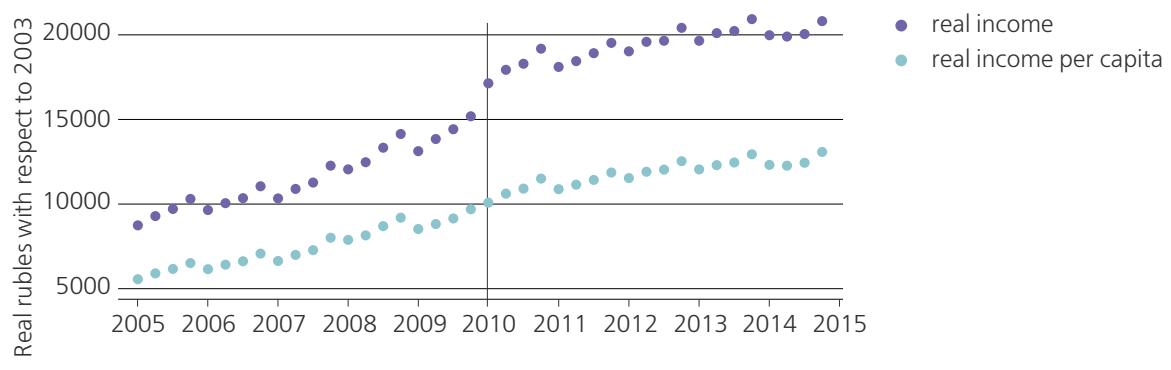

Source: HHBS, author's calculations 
The pension increase in 2010 also had an influence on Russians' living arrangement decisions. Considering the ratio of households with pensioners only to households where there are other individuals, one can see a drop in the percentage of pensioners living alone (see Figure 13). Furthermore, in the households with pension receivers, the presence of children increased (see Figure 14). The consequence of these changes was an increased number of members of retired households (see Figure 15). Remarkably, the real income of retired households per capita did not have a discontinuity in contrast to the total real income of retired households (see Figure 16).

\section{Some historical evidence, robustness checks, and the heterogeneity}

The pension increase in 2010Q1 is a part of a long ongoing series of rises. Pensioners' income changes have a very special pattern. The relative income of retired individuals and households follows the cycles of the anniversaries of the victory in World War II (see Figure A1, Appendix A). Regressions (see Table A1, Appendix A) show that there are peaks in the anniversaries relative to the trend and the years around anniversaries.

I check for the absence of discontinuities in pre-determinant covariaties that may potentially confound my results. The rate of pensioners as a share of the population increased smoothly between the years 2004 and 2015 (see Figure A2, Appendix A). I also look at the percentage of pension receivers with higher education. Figure A3, Appendix A, illustrates that nothing extraordinary happened with this percentage in the period of pension increase.

I do robustness checks for three of my major results. First, I do a robustness check for extra entry into retirement. Naturally, the subgroups of pensioners are expected to experience the influence of pension increase as well. Figure A4, Appendix A, shows a discontinuity in the percentage of retired people among people older than 65. Thus, the result of extra entry into retirement is robust to the choice of this older age group.

Next, I do a robustness check for the jump in NLFJ (see Table A2, Appendix A). I include the indicators of jumps in 2009 and 2011, and I also include the products of these indicators of jumps and the indicators of the presence of pensioners in households in the basic regression. The coefficients for these products of indicators are statistically insignificant. However, the coefficient for the product of the indicator of a jump in 2010 and the indicator of a pensioner's presence in a household remain statistically significant. This means that my result on the discontinuity in NLFJ is robust for this check.

Finally, I do a robustness check for the jump in the number of the retired households. To do this, I analyse a specific industry. It is natural to expect the effect of pension increase on employment to be the most obvious for unskilled 
labour. I look at wholesale and retail sales as such menial work. Based on the HHBS data, I measure the employment only of the head of household and her/his spouse. I concentrate on the employment of the head of household. Figure A5, Appendix A, shows a discontinuity in the employment of heads of household working in wholesale and retail sales for households with pension receivers and an absence of any jumps in that for households without pension receivers. Thus, my result on the discontinuity in the number of the retired households is robust for this check.

Then I check for the heterogeneity of the effect with respect to the type of organisation a person works in and with respect to the person's education. In order to see the former type of heterogeneity, I look at the following ratio: the number of employed retirees living in a certain type of household to all retirees. I consider households where the head and the spouse of the head work only in the public sector, only in the private sector, and in both the public and private sectors. I see that in absolute terms the public sector was influenced the most (see Figure B1, Appendix B). However, this is driven by the size of the public sector in the Russian economy. If one looks at log percentages, it becomes apparent that the influence of pension increase was similar across different sectors in relative terms (see Figure B2, Appendix B). At last, I consider heterogeneity with respect to pensioners' education. The effect of pension increase on the labour participation of retirees with and without higher education is very similar both in absolute and relative terms (see Figures B3, B4, Appendix B).

\section{Discussion}

The relative income of retirees follows cycles which are driven by the anniversaries of the victory in World War II. The relative income of other groups of people who receive money from the federal budget depends on these anniversaries much less. The possible opportunistic cycles for pensions are a minor issue compared to these 'anniversary' cycles. Thus, the Russian government does not appear to use increases in pensions specifically to win elections.

As noted, the most significant increase by magnitude happened in 2010, the 65 th anniversary of the victory in World War II. The absolute real income of pension receivers tended to rise before 2010. Then there was a significant jump in the income of retired households and pensioners in 2010. Later, the real income of pensioners did not change significantly.

One of the most significant consequences of the 2010 pension increase is a jump in the percentage of pensioners who chose to retire. From 2003 to 2015, there was an inclination that pensioners were more and more employed. Only the sharp 2010 pension rise was capable of changing this tendency. This signals the presence of a reference point in pensioners' minds when they consider labour force participation decisions. 
Due to the pre-existing situation (see Figure 7) and different employment incentives (e.g. consider the possibility of household production for rural dwellers), the effect on labour markets in rural areas and in the megalopolises was quite heterogeneous. The labour markets of the largest Russian cities, Moscow and Saint Petersburg, were influenced more than those of rural areas both in absolute and relative terms. However, for cases when employment incentives were not so obviously different, the effect was rather homogeneous.

It was not only pension receivers who stopped working and looking for jobs, but also people who lived with them during the pension increase. As the comparison of total and per capita real income of retired HHs shows (see Figure 16), younger people absorbed all additional money from the government by changing their living arrangements. The comparison of the labour force participation of younger individuals living separately from pensioners and those living together with them implies (see Figure 11) that younger people used this additional money so as to not to work, at least for some period of time.

What can policy makers learn from my findings? My research shows that pension increases influence not only pensioners, but people living with them, too. The share of persons living with pensioners among all people not eligible for pensions throughout 2005-2015 was quite large, specifically 17\%-19\%. My findings suggest that an increase in pensions can result in falling labour force participation among this group. If some pension increase in Russia leads to an $X$ p.p. rise in retirement, it will also lead to a $0.4^{\star} X$ p.p. drop in labour force participation among younger individuals who live together with pension receivers or who will start living together with pensioners after this pension increase. In addition, it appears that the effect of changes in the pension system influences rural areas and large cities very differently.

As stated above, a jump in the percentage of people who were not working among individuals below the pension age and living with pensioners - was identified. However, the trends of employment of these individuals and their peers living separately from pensioners did not change. These two results combined can be used in the debates about the current pension reform.

Some politicians say that senior people who stay at work longer due to the new pension age will take the jobs of younger people. ${ }^{22}$ The results of my research speak against this view. In particular, my paper illustrates that younger individuals do not massively take job positions which became vacant after senior people's retirement. In contradiction with the view of substitution, some group of younger people, namely those living with pensioners, quit jobs, too.

The evidence from the 2010 Russian pension increase also supports the idea that significant increases in income have a positive influence on the coresidence of generations in the country. Since people react well to financial incentives, the government can exploit this relationship of living arrangements and financial

22 e.g. see https://rg.ru/2015/03/12/kvoti.html 
incentives to nudge younger people to live together with seniors. Coresidence with other people is important for older generations: loneliness is often listed as one of the biggest fears for this group. ${ }^{23}$

\section{Conclusion}

The paper studies the effects of the pension increase in Russia in 2010 on the labour force participation decisions and living arrangements of senior people and their family members. The rise led to an approximately 5 p.p. increase in the share of pension receivers who chose to retire. The effect on the labour market depended heavily on the type of settlement. In the biggest Russian cities the effect was greater. One out of four employed pensioners left the labour force in Moscow and Saint Petersburg. Also, I find an external effect on people who live with pensioners. The regression shows that in 2010Q1 there was no jump in the percentage of unemployed people not looking for a job for a whole quarter among those who lived separately from pensioners. Meanwhile, the increase in this percentage among those who lived with pension receivers was a slightly above 2 p.p. Additionally, the coresidence of pensioners with other generations went up. Thus, the paper shows that the pension increase influenced people who did not receive pensions themselves.

The research can be extended in different ways. Since the labour markets of Moscow and Saint Petersburg experienced the largest influence of the 2010 pension increase, more rigorous analysis of the effects of this pension increase on the labour markets of these cities is of particular interest. In addition, the consequences of the 2010 pension increase can be studied from the viewpoints of the structural model of interactions between spouses of senior age and dynamic models of retirement decisions.

Appendices are available at

http://rjmf.econs.online/en; dx.doi.org/10.31477/rjmf.202001.92

\section{References}

Afanasiev, S. A. (2003). Pension Reform in Russia: First Year of Implementing. PIE Discussion Discussion Paper, N 146. Available at: http://hermes-ir.lib.hit-u.ac.jp/rs/ bitstream/10086/14467/1/pie_dp146.pdf [accessed on 31 December 2019].

Angrist, J. and Pischke, J. (2009). Mostly Harmless Econometrics: An Empiricist's Companion. Princeton University Press.

Bianchi, S. M. (1987). Living at Home: Young Adults' Living Arrangements in the 1980s. Unpublished paper, Center for Demographic Studies, US Bureau of the Census.

${ }^{23}$ See https://fom.ru/nastroeniya/12596 
Cameron, A. and Trivedi, P. (2005). Microeconometrics: Methods and Applications. Cambridge University Press.

Danielyan, V. A. (2016). Individual Determinants of Pension Age: Review of Researches. Vestnik Instituta Ekonomiki Rossijskoj Akademii Nauk, 3, pp. 171-202. [In Russian].

De Castello Branco, M. (1998). Pension Reform in the Baltics, Russia, and Other Countries of the Former Soviet Union (BRO). IMF Working Paper, N 11.

Durante, R. and Zhuravskaya, E. (2016). Attack When the World Is Not Watching? U.S. News and the Israeli-Palestinian Conflict. Journal of Political Economy, 126(3), pp. 1085-1133.

Gel'man, V., ed. (2017). Authoritarian Modernization in Russia: Ideas, Institutions, and Policies. London: Routledge. doi: 10.4324/9781315568423

Goldscheider, F. K. and DaVanzo, J. (1989). Pathways to Independent Living in Early Adulthood: Marriage, Semiautonomy, and Premarital Residential Independence. Demography, 26, pp. 597-614.

Gontmakher, E. (2009). The Pension System of Russia After the Reform of 2002: Challenges and Prospects. Journal of the New Economic Association, 1-2, pp. 190-206.

Gruber, J., Milligan, K. and Wise, D. (2009). Social Security Programs and Retirement Around the World: The Relationship to Youth Employment, Introduction and Summary. NBER Working Paper, N 14647.

Gurvich, E. and Sonina, Y. (2012). Microanalysis of the Russia's Pension System. Voprosy Ekonomiki, 2, pp. 27-51. [In Russian]. doi: 10.32609/0042-8736-2012-2-27-51

Hauner, D. (2008). Macroeconomic Effects of Pension Reform in Russia. IMF Working Paper, N 201.

Kovrova, I. (2007). Shaping a Pension System: Distributive and Incentive Effects of the Russian Pension Reforms. PhD Thesis, University of Turin.

Lee, D. S. and Lemieux, T. (2010). Regression Discontinuity Designs in Economics. Journal of Economic Literature, 48(2), pp. 281-355. doi: 10.1257/jel.48.2.281

Lokshin, M., Harris, K. M. and Popkin, B. M. (2000). Single Mothers in Russia: Household Strategies for Coping with Poverty. World Development, 28(12), pp. 2183-2198.

Lyashok V. Y. (2017). Pension, Health and Labor Demand As Determinants of Economic Activity of Elderly Population in Russia. PhD Thesis, Higher School of Economics. [In Russian]. Available at: https://www.prlib.ru/item/1155798 [accessed on 21 February 2020].

Maleva, T. and Sinyavskaya, O. (2010). Pension Age Increase: Pro et Contra. Journal of the New Economic Association, 8, pp. 117-137.

Malkova, O. (2020). Did Soviet Elderly Employment Respond to Financial Incentives? Evidence from Pension Reforms. Journal of Public Economics, 182. Article in press. doi.org/10.1016/j.jpubeco.2019.104111.

Manacorda, M. and Moretti, E. (2006). Why Do Most Italian Youths Live with Their Parents? Intergenerational Transfers and Household Structure. Journal of the European Economic Association, 4(4), pp. 800-829. doi: 10.1162/JEEA.2006.4.4.800 
Manoli, D. and Weber, A. (2016). Nonparametric Evidence on the Effects of Financial Incentives on Retirement Decisions. American Economic Journal: Economic Policy, 8(4), pp. 160-182.

Schröder-Butterfill, E. (2004). Inter-generational Family Support Provided by Older People in Indonesia. Ageing and Society, 24(4), pp. 497-530. doi: 10.1017/ S0144686X0400234X

Sinyavskaya, O. (2005). Pension Reform in Russia: A Challenge of Low Pension Age. PIE Discussion Paper, N 267. Available at: http://cis.ier.hit-u.ac.jp/Common/pdf/ dp/2004/dp267.pdf [accessed on 21 February 2020].

Solovyev, A. (2013). The Macroanalysis of Russian Pension System. Voprosy Economiki, 4, pp. 82-93. [In Russian]. doi: 10.32609/0042-8736-2013-4-82-93

Young, C. (1987). Young People Leaving Home in Australia: The Trend Towards Independence. Australian Family Formation Project Monograph, N 9. 